\title{
PENGARUH KESADARAN MEREK DAN CITRA MEREK TERHADAP LOYALITAS PELANGGAN TEH PUCUK HARUM WILAYAH SURABAYA UTARA
}

\author{
Anik Lestari Andjarwati* dan Eka Chusniartiningsih \\ Universitas Negeri Surabaya
}

\begin{abstract}
ABSTRAK: Tujuan penelitian ini adalah untuk melakukan eksaminasi atas pengaruh kesadaran merek, dan citra merek terhadap loyalitas pelanggan Teh Pucuk Harum. Penelitian ini merupakan penelitian kausalitas dengan pendekatan kuantitatif. Metode pengumpulan data adalah denga menggunakanan metode pengambilan sampel non-probabilitas sejumlah 220 orang di Surabaya utara. Pengolahan uji statistik dilakukan dengan menggunakan analisis linear berganda. Hasil penelitian mendapati kesadaran merek berpengaruh positif dan signifikan terhadap loyalitas pelanggan, dan citra merek juga memiliki pengaruh positif dan signifikan terhadap loyalitas pelanggan.
\end{abstract}

Kata Kunci: Kesadaran Merek, Citra Merek, dan Loyalitas Pelanggan

Abstract: The purpose of this study is to examine and analyze the effect of brand awareness and brand image to customer loyalty on customer of Teh Pucuk Harum. This research is a causality research with quantitative approach. Technique of sampling using non probability sampling with amount 220 respondents in North Surabaya. Statistical analysis in this study is multiple linier. The results of this study explain that brand awareness had a positive and significant effect on the customer loyalty, and brand image had a positive and significant effect on the customer loyalty.

Keywords: Brand Awareness, Brand Image, and Customer Loyalty.

*Surel korespondensi penulis: aniklestari@unesa.ac.id

DOI: $10.24252 /$ minds.v5i2.6736

ISSN-E: 2597-6990

http://journal.uin-alauddin.ac.id/index.php/minds 


\section{PENDAHULUAN}

Pada tahun 2016 jumlah penduduk Indonesia sebanyak 258,7 juta orang berdasarkan Badan Pusat Statistik, dengan jumlah penduduk yang banyak tersebut menjadikan Indonesia sebagai pasar yang sangat menjanjikan untuk industri makanan dan minuman. Industri tersebut mampu memberikan kontribusi Produk Domestik Bruto (PDB) Indonesia tertinggi dibandingkan industri lainnya di sektor non migas yang mencapai $34,95 \%$ di triwulan III tahun 2017 (Syaefudin, 2017). Kontribusi tinggi industri makanan dan minuman di triwulan III tahun 2017 tersebut karena pertumbuhan industri makanan dan minuman mengalami kenaikan mencapai 9,46\%. Dari kenaikan industri tersebut yang memberikan konstribusi tinggi adalah dari industri minuman yang mencapai $7,7 \%$ sedangkan sisanya kontribusi dari industri makanan (Azzura, 2017).

Industri minuman terdiri dari berbagai macam kategori salah satunya adalah teh. Konsumsi teh di Indonesia sangat tinggi yakni sebesar 0,5 $\mathrm{kg} / \mathrm{kapita}$ (129.350 ton) pada tahun 2017. Sehingga untuk memenuhi konsumsi yang tinggi tersebut, Indonesia harus melakukan impor teh yang mencapai 1.849 ton (Idris, 2017). Industri teh di Indonesia terbagi menjadi dua kategori, yakni teh regular dan teh siap minum. Kategori teh regular yang termasuk di dalamnya adalah teh celup dan teh seduh, sedangkan kategori teh siap minum adalah teh kemasan siap minum. Berdasarkan survey dari Nielsen Consumer Media View menunjukkan bahwa pada 2016 konsumen teh siap minum (ready to drink/RTD) mencapai 22\%. Sedangkan konsumen teh reguler sekitar $11 \%$.

Pada tahun 2016 secara keseluruhan teh kemasan siap minum mampu menguasai $30 \%$ dari pasar minuman ready to drink / RTD. Urutan tersebut setelah air mineral yang mencapai $40 \%$, ketiga oleh minuman berkarbonasi sebesar 20\%, dan 10\% kategori minuman kemasan yang lainnya. Sehingga, banyak sekali para pemain yang terjun ke dalam industri Teh Siap Minum (RTD Tea) di Indonesia (Imeikom, 2016). Untuk mampu menguasai pasar Teh RTD perusahaan berusaha menerapkan strategi pemasaran yang dibangun berdasarkan kepada pemahaman yang lebih baik dari perilaku konsumen (Sumarwan, 2015).

Menurut Schiffman \& Kanuk (2008:6), perilaku konsumen merupakan perilaku yang terpusat pada cara seseorang dalam mengambil keputusan dengan memanfaatkan sumber daya yang mereka miliki untuk membeli barang-barang yang berkaitan dengan konsumsi. Menurut Kotler \& Keller (2012:166), ada lima tahap dalam proses pengambilan keputusan yakni, pengenalan kebutuhan, pencarian informasi, evaluasi alternatif, keputusan pembelian, dan perilaku pasca pembelian. Perilaku konsumen dipengaruhi oleh tiga faktor utama yakni, perbedaan individu, faktor lingkungan, dan stimulus dari pemasar. Stimulus yang diberikan oleh pemasar atau perusahaan bertujuan agar dapat menjual produk yang dihasilkannya kepada konsumen. Perusahaan membutuhkan konsep pemasaran dan juga strategi pemasaran yang kuat untuk menjadikan produknya dapat dan siap bersaing dengan para 
kompetitornya, hal tersebut untuk merebut simpati konsumen, membentuk pengalaman yang mengesankan konsumen, membentuk kepercayaan konsumen, dan menciptakan konsumen yang percaya menjadi pelanggan yang loyal.

Di Indonesia banyak perusahaan pemain industri minuman teh kemasan siap minum (RTD Tea) salah satunya adalah PT Mayora Indah Tbk yang mana pada tahun 2011 meluncurkan merek teh kemasan siap minum bernama Teh Pucuk Harum. Meski baru sekitar lima tahun berjalan, merek ini dapat dibilang sukses saat ini. Dalam membangun merek teh kemasan siap minum, Teh Pucuk Harum melakukan berbagai strategi untuk menggaet pasar yang lebih luas dibandingkan dengan merek-merek minuman teh kemasan siap minum lainnya. Teh Pucuk Harum mampu mengeluarkan biaya iklan yang sangat besar untuk menggaet pasar RTD teh yang sangat kompetitif, biaya iklan tersebut mencapai Rp 381,7 Milyar sepanjang tahun 2016.

Dalam hal membangun kesadaran merek (brand awareness), Teh Pucuk Harum menerapkan strategi komunikasi yang unik dan berbeda dari pesaingnya. Melalui iklan menarik di media televisi dengan jalan cerita yang unik. Strategi yang diterapkan Teh Pucuk Harum ini juga berfungsi untuk membangun citra merek positif di benak konsumen. Selain itu, Teh Pucuk Harum menggunakan bahan-bahan baku yang berkualitas tinggi yaitu pucukpucuk daun teh yang diseleksi ketat untuk menghasilkan kualitas rasa teh putih dari Teh Pucuk Harum menjadi sangat terjamin serta menggunakan proses produksi dengan teknologi mutakhir dan modern. Dengan berbagai strategi tersebut mampu membuat TBI Teh Pucuk Harum melonjak tajam hingga enam kali lipat di tahun 2016 dibandingkan tahun sebelumnya. Jika pada tahun 2015 TBI Teh Pucuk Harum sebesar 4.1\%, tahun 2016 TBI Teh Pucuk Harum mencapai 24.8\%. Pada tahun 2017 TBI Teh Pucuk Harum juga mengalami kenaikan meskipun tidak signifikan yakni menjadi 25,7\%.

Namun, dari strategi dan pencapaian kelonjakan TBI tersebut tidak berbanding lurus dengan market share dari Teh Pucuk Harum yang mana market share Teh Pucuk Harum mengalami penurunan pada tahun 2016 ke tahun 2017 dimana semula di tahun 2016 sebesar 20,8\% turun menjadi 17,7\% di tahun 2017. Selain itu, future intention dari Teh Pucuk Harum juga mengalami penurunan sebesar 4,8\% dimana yang semula bulan Januari 2017 sebesar 70,8\% turun menjadi 66\% pada bulan Juli 2017.

Penelitian ini dilakukan di wilayah Surabaya Utara karena berdasarkan keterangan Bagus Sudikerto bagian penjualan PT Tirta Fresindo Jaya, wilayah Surabaya bagian utara adalah wilayah yang paling besar distribusinya dibandingkan wilayah Surabaya yang lainnya hingga mencapai 30\% tahun 2017. Distribusi paling banyak dilakukan oleh PT Tirta Fresindo Jaya ke supermarket dan minimarket yang ada di wilayah Surabaya Utara. Tujuan dari penelitian ini adalah untuk menganalisis dan membahas pengaruh kesadaran merek dan citra merek terhadap loyalitas pelanggan pada pelanggan Teh Pucuk Harum. 


\section{TINJAUAN TEORITIS}

Loyalitas Pelanggan (Customer Loyalty)

Loyalitas ialah komitmen yang dipegang teguh oleh konsumen untuk membeli atau mendukung kembali produk baik barang maupun jasa di masa yang akan datang meskipun dipengaruhi oleh situasi dan usaha pemasaran lain yang dapat menyebabkan pelanggan beralih (Kotler \& Keller, 2012:127). Menurut Vanessa (2007:71-72), faktor yang memengaruhi loyalitas adalah ikatan emosi (emotional bonding), dalam ikatan emosi konsumen dapat terpengaruh oleh sebuah merek yang memiliki daya tarik tersendiri Sehingga sebuah merek dianggap sangat penting untuk terciptanya ikatan emosi yang dihasilkan.

Kesadaran Merek (Brand Awareness)

Keller (2013:72), mendefinisikan kesadaran merek (brand awareness) terkait dengan kekuatan simpul atau jejak merek di memori, yang dapat diukur sebagai kemampuan konsumen mengidentifikasi merek dengan kondisi yang berbeda. Sedangkan Aaker (1991:73), mengemukakan bahwa kesadaran merek ialah kemampuan calon pembeli dalam mengingat merek adalah link antara kelas produk dan merek yang terlibat. Menurut Jacoby et al (1977) dalam Mathew et al (2014) kesadaran dapat mempengaruhi keputusan pembelian tentang merek di set pertimbangan yang, pada gilirannya, akan meningkatkan loyalitas bahkan jika tidak ada asosiasi merek lain. Dalam menetapkan merek seorang pemasar harus memikirkan strategi yang tepat karena penetapan merek akan mempengaruhi proses pembelian konsumen, proses pemberian nilai terhadap perusahaan, dan menandakan loyalitas konsumen. Maka dari itu, kegiatan membangun merek dapat dibenarkan, dalam membangun merek melalui aset yang mendasari ekuitas merek (Aaker, 1991:27). Menurut Aaker (1991:28), terdapat lima kategori yang mendasari ekuitas merek, yakni kesadaran merek (brand awareness), asosiasi merek (brand associations), persepsi kualitas (perceived quality), loyalitas merek (brand loyalty), dan aset-aset merek lainnya (other proprietary brand assets).

Menurut Aaker (1991:219), menyatakan bahwa kesadaran merek dan bahkan tingkat kualitas dan kepercayaan yang dirasakan seringkali tidak memadai di kemudian hari, biasanya perlu ada diferensiasi yang relevan untuk merangsang pembelian dan juga loyalitas. Hal tersebut didukung oleh hasil penelitian Ahmad (2016) yang menunjukkan ada hubungan langsung antara kesadaran merek dengan loyalitas pembelian ulang pelanggan. Dalam penelitian Nguyen (2011) juga menunjukkan bahwa ada hubungan positif antara kesadaran merek dengan loyalitas suatu merek. Namun, penelitian Subhani \& Osman (2011) menunjukkan hasil berbeda yakni hubungan antara kesadaran merek baik dari brand recall maupun brand recognition terhadap pembelian ulang tidak signifikan. Hasil penelitian Mathew et al (2014) dan penelitian Tandarto \& Dharmayanti (2017) juga menunjukkan hasil bahwa tidak ada pengaruh signifikan dari brand awareness terhadap customer loyalty. 
Selanjutnya, berdasarkan teori tersebut hipotesis pada penelitian ini adalah sebagai berikut:

$\mathrm{H}_{1}$ : Ada pengaruh kesadaran merek terhadap loyalitas

Citra Merek (Brand Image)

Keller (2013:72), citra merek (brand image) merupakan persepsi konsumen akan suatu merek, seperti tercermin dari asosiasi merek yang dimiliki pada memori konsumen. Sedangkan menurut Aaker (1991:164), citra merek ialah asosiasi unik yang dibuat oleh pemasar. Asosiasi tersebut berkaitan dengan apa arti sebuah merek dan yang dijanjikan kepada konsumen. Menurut Hsieh et al (2004) dalam Ahmad et al (2016) menyatakan bahwa menaikkan loyalitas, niat membeli kembali dan keseluruhan kinerja merek adalah efek yang baik citra merek bagus. Aset ekuitas merek lainnya yang menjadi salah satu faktor yang mempengaruhi loyalitas pelanggan yakni citra merek. Menurut Rangkuti (2002:44), mengatakan bahwa konsumen menganggap bahwa suatu merek tertentu memiliki fisik berbeda dari merek kompetitor, citra merek tersebut akan melekat secara terus menerus sehingga dapat membentuk kesetiaan terhadap merek tertentu yang dinamakan dengan dengan loyalitas. Hal tersebut didukung dengan hasil penelitian Ahmad et al (2016) bahwa ada hubungan signifikan antara citra merek dengan loyalitas pembelian ulang pelanggan. Hasil penelitian dari Ransulangi dkk (2017) dan Wijayanto \& Iriani (2013) menunjukkan bahwa ada hubungan yang positif antara citra merek dengan loyalitas pelanggan. Namun, hasil penelitian Alwi et al (2016) menunjukkan bahwa citra merek suatu industri tidak mempengaruhi loyalitas suatu merek. Selanjutnya, berdasarkan teori tersebut hipotesis pada penelitian ini adalah sebagai berikut:

$\mathrm{H}_{2}$ : Ada pengaruh citra merek terhadap loyalitas pelanggan.

\section{METODE PENELITIAN (METHODOLOGY)}

\section{Rancangan Penelitian}

Pada penelitian ini, rancangan penelitian yang digunakan ialah rancangan penelitian konklusif. Dimana rancangan penelitian konklusif memiliki tujuan yakni menguji hipotesis dan menguji hubungan dengan data yang dihasilkan dan dianalisis secara kuantitatif (Malhotra, 2009:90).

Adapun rancangan penelitian yang dibuat dalam penelitian ini yakni untuk mengetahui apakah terdapat pengaruh kesadaran merek dan citra merek terhadap loyalitas pelanggan (studi pada pelanggan Teh Pucuk Harum wilayah Surabaya Utara) dapat dilihat pada gambar berikut: 


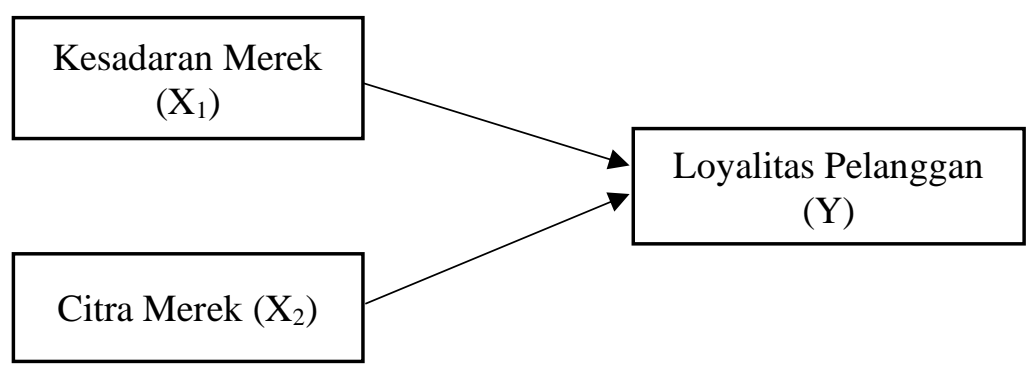

Sumber: diolah Penulis

\section{Gambar 1. Kerangka Konseptual}

Populasi

Populasi dalam penelitian ini adalah populasi yang bersifat infinite artinya jumlah populasi yang akan diteliti belum diketahui. Populasi dalam penelitian ini adalah pelanggan Teh Pucuk Harum yang berusia 19 tahun hingga 68 tahun di wilayah Surabaya Utara dan pernah membeli serta mengkonsumsi Teh Pucuk Harum minimal 2 kali dengan jangka waktu satu bulan terakhir.

Sampel

Jumlah sampel dalam penelitian ini sebanyak 220 responden. Teknik sampling dalam penelitian ini menggunakan nonprobability sampling. Metode pengambilan sampel yang digunakan ialah purposive sampling.

Definisi Operasional

Berikut adalah apendiks definisi operasional yang berisi variabel, indikator dan item yang digunakan dalam penelitian ini, bisa dilihat di akhir naskah ini.

Teknik Analisis Data

Teknik analisis data dalam penelitian ini menggunakan teknik analisis deskriptif dan inferensial. Untuk pengujian hipotesis, penelitian ini menggunakan teknik analisis regresi linier berganda yang diolah dengan menggunakan software SPSS versi 22.0. 
HASIL

Karakteristik Responden

Tabel 2

KARAKTERISTIK RESPONDEN

\begin{tabular}{|c|c|c|}
\hline \multicolumn{2}{|c|}{ Karakteristik Responden } & \multirow{2}{*}{$\begin{array}{c}\text { Jumlah } \\
130\end{array}$} \\
\hline Jenis Kelamin & Laki-Laki & \\
\hline & Perempuan & 90 \\
\hline \multicolumn{2}{|c|}{ Total } & 220 \\
\hline \multirow[t]{5}{*}{ Usia } & 19-28 tahun & 113 \\
\hline & 29-38 tahun & 44 \\
\hline & 39-48 tahun & 45 \\
\hline & 49-58 tahun & 18 \\
\hline & 59-68 tahun & 0 \\
\hline \multicolumn{2}{|c|}{ Total } & 220 \\
\hline \multirow[t]{6}{*}{ Pekerjaan } & Mahasiswa & 44 \\
\hline & PNS & 16 \\
\hline & Wiraswasta & 25 \\
\hline & Karyawan Swasta & 79 \\
\hline & Ibu Rumah Tangga & 39 \\
\hline & Lainnya & 17 \\
\hline \multicolumn{2}{|c|}{ Total } & 220 \\
\hline
\end{tabular}

Sumber : data diolah penulis

Berdasarkan tabel 2 di atas maka responden yang mendominasi dalam penelitian ini adalah responden yang berjenis kelamin laki-laki sebanyak 130 responden, berdasarkan usia yang mendominasi adalah responden yang berusia 19 - 28 tahun sebanyak 113, dan berdasarkan jenis pekerjaan responden yang mendominasi adalah responden yang bekerja sebagai karyawan swasta sebanyak 79.

\section{Uji Asumsi Klasik}

Uji Asumsi Klasik terdiri dari uji normalitas, uji multikolinieritas, dan uji heterokedastisitas. Pada uji normalitas, model regresi linier berganda memenuhi asumsi normalitas karena titik-titik grafik normal P Plot menyebar dan mengikuti garis diagonalnya. Pada uji multikolinieritas, nilai tolerance dari seluruh variabel bebas pada penelitian ini sebesar 0.918 atau lebih besar dari 0.10 dan nilai VIF dari seluruh varibel bebas pada penelitian ini sebesar 1.089 atau kurang dari 10. Pada uji heterokedastisitas, nilai t hitung lebih besar dari 0.05 yang artinya tidak ada signifikansi. 
Hasil Analisis Regresi Linear Berganda

Tabel 3

HASIL ANALISIS REGRESI LINIER BERGANDA

\begin{tabular}{lccccc}
\hline \multicolumn{5}{c}{ Unstadarized Coefficients } & \\
\hline Model & $\mathrm{B}$ & Std.Error & Beta & $\mathrm{t}$ & Sig \\
(Constanta) & 4.240 & 2.651 & & 1.599 & 0.111 \\
X1 & 0.943 & 0.071 & 0.664 & 13.220 & 0.000 \\
X2 & 0.057 & 0.025 & 0.117 & 2.322 & 0.021 \\
\hline
\end{tabular}

Sumber : data diolah penulis

Nilai konstanta pada tabel 3 tersebut adalah 4.240, maka dapat dijelaskan bahwa kesadaran merek dan citra merek bernilai 0 (nol) maka besaran nilai loyalitas pelanggan adalah 4.240.

Nilai koefisien untuk variabel kesadaran merek adalah 0.943, maka dapat dijelaskan bahwa setiap kesadaran merek mengalami kenaikan satu satuan, maka loyalitas pelanggan akan mengalami peningkatan sebesar 0.943. Kemudian nilai koefisien untuk variabel citra merek adalah 0.057, maka dapat dijelaskan bahwa setiap citra merek mengalami kenaikan satu satuan, maka loyalitas pelanggan akan mengalami peningkatan sebesar 0.057 . Tanda positif menunjukkan jika kesadaran merek $\left(\mathrm{X}_{1}\right)$ dan loyalitas pelanggan $(\mathrm{Y})$ memiliki hubungan yang searah, yang artinya semakin tinggi kesadaran merek maka akan semakin tinggi loyalitas pelanggan pelanggan Teh Pucuk Harum. Begitu pula tanda positif yang ada variabel ke dua menunjukkan jika citra merek $\left(\mathrm{X}_{2}\right)$ dan loyalitas pelanggan (Y) memiliki hubungan yang searah, yang artinya semakin baik citra merek maka akan semakin tinggi loyalitas pelanggan pelanggan Teh Pucuk Harum

Uji Kelayakan Model

Tabel 4

NILAI R (KORELASI) DAN R2 (KOEFISIEN DETERMINASI)

\begin{tabular}{ccccc}
\hline Model & R & R Square & $\begin{array}{c}\text { Nilai Adjusted R } \\
\text { Square }\end{array}$ & $\begin{array}{c}\text { Std.Error of the } \\
\text { Estimate }\end{array}$ \\
\hline 1 & 0.706 & 0.498 & 0.493 & 5.936 \\
\hline
\end{tabular}

Sumber : data diolah penulis

Dari data tabel 4 di atas, dapat diketahui nilai Adjusted $R$ Square sebesar 0.493 atau $49.3 \%$ dimana dapat disimpulkan bahwa sebesar $49.3 \%$ variabel independen berpengaruh terhadap variabel dependen atau sebesar $49.3 \%$ variabel kesadaran merek dan citra merek berpengaruh terhadap loyalitas pelanggan Teh Pucuk Harum. 


\section{PEMBAHASAN}

Pengaruh Hubungan Kesadaran Merek terhadap Loyalitas Pelanggan

Dari hasil analisis data di atas menunjukkan bahwa ada pengaruh kesadaran merek terhadap loyalitas pelanggan. Artinya apabila kesadaran merek meningkat maka loyalitas pelanggan akan meningkat pula. Hal tersebut menjelaskan bahwa semakin tinggi kesadaran merek Teh Pucuk Harum maka semakin tinggi loyalitas pelanggan Teh Pucuk Harum. Hasil itu menunjukkan bahwa hipotesis pertama yaitu "terdapat pengaruh kesadaran merek terhadap loyalitas Teh Pucuk Harum di wilayah Surabaya Utara" terbukti kebenarannya.

Hasil tersebut membuktikan teori dari Aaker (1991:219) menyatakan bahwa kesadaran merek dan bahkan tingkat kualitas dan kepercayaan yang dirasakan seringkali tidak memadai di kemudian hari, biasanya perlu ada diferensiasi yang relevan untuk merangsang pembelian dan juga loyalitas. Sehingga dapat disimpulkan bahwa semakin tinggi kesadaran merek konsumen terhadap Teh Pucuk Harum maka semakin tinggi pula loyalitas pelanggan Teh Pucuk Harum. Teh Pucuk Harum harus terus memberikan strategi yang baik untuk meningkatkan kesadaran konsumen dan pelanggan terhadap Teh Pucuk Harum seperti melalui iklan unik dan menarik, mengiklankan melalui berbagai media secara gencar, tagline unik, dsb karena dengan strategi tersebut nantinya akan membuat konsumen terus menerus membeli ulang produk dan berujung pada loyalitas.

Hasil ini juga mendukung hasil penelitian Ahmad et al (2016) yang menunjukkan bahwa terdapat hubungan langsung antara kesadaran merek dengan loyalitas pembelian ulang pelanggan dengan objek penelitiannya adalah produk agrikultural. Dan mendukung pula penelitian Nguyen et al (2011) bahwa terdapat hubungan positif antara kesadaran merek dengan loyalitas suatu merek dengan objek penelitiannya adalah sampo. Namun menolak hasil penelitian dari Subhani \& Osman (2011) menunjuukan bahwa hubungan antara kesadaran merek baik dari brand recall maupun brand recognition terhadap pembelian ulang tidak signifikan dengan objek penelitiannya adalah susu. Serta menolak hasil penelitian Mathew et al (2014) dengan objek penelitiannya adalah deodoran dan penelitian Tandarto \& Dharmayanti (2017) dengan objek penelitiannya adalah kopi yang menyatakan bahwa tidak terdapat pengaruh signifikan dari brand awareness terhadap customer loyalty. Sehingga dapat disimpulkan bahwa dalam penelitian ini untuk mencapai loyalitas pelanggan Teh Pucuk Harum dapat dipengaruhi oleh kesadaran merek, meskipun menolak hasil penelitian dari Subhani \& Osman (2011), Mathew et al (2014) dan Tandarto \& Dharmayanti (2017) pengaruh kesadaran merek terhadap loyalitas pelanggan dilihat dari objek penelitian yang berbeda masih dapat digeneralisasikan karena kategori produk masingmasing penelitian tersebut masih dalam kategori yang sama yakni convinience goods.

Apabila dikaitkan dengan karakteristik responden maka responden yang loyal dengan merek Teh Pucuk Harum dengan tingkat kesadaran merek paling 
tinggi yakni laki-laki berusia 19 - 28 tahun. Hal ini dikarenakan strategi komunikasi yang unik dan menarik Teh Pucuk Harum mampu membuat pelanggannya loyal dan terus menerus melakukan pembelian ulang terutama bagi pelanggan dengan rentang usia 19 - 28 tahun yang menyukai minuman kemasan siap minum.

\section{Pengaruh Citra Merek Terhadap Loyalitas Pelanggan}

Dari hasil analisis data di atas menunjukkan bahwa ada pengaruh citra merek terhadap loyalitas pelanggan. Artinya apabila citra merek semakin baik maka loyalitas pelanggan semakin meningkat meskipun prosentasenya kecil. Hasil itu menunjukkan bahwa hipotesis kedua yaitu "terdapat pengaruh citra merek terhadap loyalitas Teh Pucuk Harum di wilayah Surabaya Utara" terbukti kebenarannya.

Hasil penelitian ini sesuai dengan teori yang dikemukakan oleh Rangkuti (2002:44) yang mengatakan bahwa apabila konsumen menganggap bahwa suatu merek tertentu memiliki fisik berbeda dari merek kompetitor, citra merek tersebut akan melekat secara terus menerus sehingga dapat membentuk kesetiaan terhadap merek tertentu yang dinamakan dengan dengan loyalitas.

Hasil penelitian ini mendukung hasil dari penelitian Ahmad et al (2016) bahwa terdapat hubungan yang signifikan antara citra merek dengan loyalitas pembelian ulang pelanggan dengan objek penelitiannya adalah produk agrikultural dan juga mendukung hasil penelitian dari penelitian Ransulangi dkk (2017) dengan objek penelitiannya adalah minuman teh dan Wijayanto \& Iriani (2013) dengan objek penelitiannya adalah kopi yang menunjukkan bahwa terdapat hubungan yang positif antara citra merek dengan loyalitas pelanggan. Namun hasil penelitian ini bertentangan dengan hasil penelitian Alwi et al (2016) menunjukkan bahwa citra merek suatu industri tidak berpengaruh signifikan terhadap loyalitas suatu merek dengan objek penelitiannya adalah makanan dan minuman. Sehingga dapat disimpulkan bahwa citra merek berpengaruh terhadap loyalitas pelanggan meskipun objek penelitian dari masing-masing penelitian berbeda namun masih dapat digeneralisasikan karena kategori produk masing-masing penelitian tersebut masih dalam kategori yang sama yakni convinience goods.

Apabila dikaitkan dengan karakteristik responden maka secara keseluruhan responden terutama yang berjenis kelamin laki-laki dengan rentang usia 19 - 28 tahun yang loyal terhadap merek Teh Pucuk Harum memerhatikan citra mereknya saat melakukan pembelian meskipun prosentase memerhatikan citra merek saat membeli Teh Pucuk Harum kecil. Hal tersebut kemungkinan bisa terjadi karena Teh Pucuk Harum bukanlah produk yang membutuhkan pertimbangan mendalam mengenai citra merek dalam memilih atau membelinya secara berulang-ulang. Teh Pucuk Harum merupakan kategori produk convinience yang biasanya sering dibeli dengan perilaku pembelian dilakukan secara cepat dan dengan upaya yang sedikit (Kotler \& Keller, 2012:327). Dalam pembelian yang dilakukan secara berulang-ulang 
(habitual buying) kebutuhan dalam memilih merek seringkali tidak selalu diperhatikan karena pembelian dilakukan atas dasar kebutuhan bukan keinginan.

\section{KESIMPULAN}

Berdasarkan hasil analisis data dan pembahasan hasil penelitian, maka dapat disimpulkan Ada pengaruh signifikan kesadaran merek terhadap loyalitas pelanggan (Studi pada pelanggan Teh Pucuk Harum Wilayah Surabaya Utara). Dan ada pengaruh yang signifikan citra merek terhadap loyalitas pelanggan (Studi pada pelanggan Teh Pucuk Harum Wilayah Surabaya Utara).

\section{KETERBATASAN PENELITIAN}

Keterbatasan dari penelitian ini adalah kurang spesifik dalam membedakan variabel kesadaran merek dengan variabel citra merek sehingga menyebabkan item-item pernyataan di dalamnya terlihat seperti mirip dan kalimatnya berulang-ulang. Sehingga disarankan kepada peneliti selanjutnya untuk benar-benar membedakan secara spesifik antara variabel kesadaran merek dengan variabel citra merek agar mendapatkan hasil penelitian yang lebih relevan.

\section{DAFTAR PUSTAKA}

Aaker, D. A. (1991). Managing Brand Equity. New York: Free Press.

Ahmad, Z., Jun, M., Khan, I., Abdullah, M., \& Gahuri, T. A. (2016). Examining Mediating Role of Customer Loyalty for Influence of Brand Related Attributes on Customer Repurchase Intention. Journal of Northeast Agricultural University (English Edition), 23(2), 89-96.

Ahmed, Z., Rizwan, M., Ahmad, M., \& Haq, M. (2014). Effect of Brand Trust and Customer Satisfaction on Brand Loyalty in Bahawalpur. Journal of Sociology Research, 5(1), 306-326.

Alwi, S. F. S., Nguyen, B., Melewar, T., Loh, Y. H., \& Liu, M. (2016). Explicating Industrial Brand Equity : Integrating Brand Trust, Brand Performance and Industrial Brand Image. Industrial Management \& Data Systems, 116(5).

Azzura, S. N. (2017). Kuartal III 2017, industri minuman tumbuh paling tinggi. Retrieved March 22, 2018, from https://www.merdeka.com

Idris, M. (2017). Januari-Februari 2017, RI Impor Kopi dari Brasil Hingga Vietnam. Retrieved March 22, 2018, from ttps:// finance.detik.com

Imeikom. (2016). Bisnis Minuman Ready to Drink: Cerah Tapi Ketat. Retrieved October 29, 2017, from http:/ / imeikom.com

Keller, K. L. (2013). Strategic Brand Manajemen Building, Measuring, ang Managing Brand Equity. United State: Pearson Education, Inc.

Kotler, P., \& Keller, K. L. (2012). Marketing Management 14th Edition. Jakarta: Erlangga. 
Mathew, V., Ali, R. ofinThirunelvelikaran M., \& Thomas, S. (2014). Loyalty Intentions: Does The Effect of Commitment, Credibility and Awareness Vary Across Consumers with Low and High Involvement? Journal of Indian Business Research, 6(3), 213-230.

Nguyen, T. D., Barrett, N. J., \& Miller, K. E. (2011). Brand Loyalty in Emerging Markets. Marketing Intelligence \& Planning, 29(3), 222-232.

Rangkuti, F. (2002). Measuring Customer Satisfaction Teknik Mengukur dan Strategi Meningkatkan Kepuasan Pelanggan dan Analisis Kasus PLN-JP. Jakarta: PT. Gramedia Pustaka Utama.

Ransulangi, G. S. T., Waney, N. F. L., \& Dumai, J. N. K. (2017). Pengaruh Komponen Citra Merek (Brand Image) Terhadap Loyalitas Konsumen Produk Minuman Share Tea di Kota Manado. Agri-Sosio Ekonomi Unsrat, 13(2), 79-86.

Schiffman, L., \& Kanuk, L. L. (2008). Perilaku Konsumen (tujuh). Jakarta: PT Indeks.

Subhani, M. I., \& Osman, M. A. (2011). A Study on The Association Between Brand Awareness and Consumer/Brand Loyalty for The Packaged Milk Industry in Pakistan. South Asian Journal of Management Sciences, 5(1), 11-23.

Sumarwan, U. (2015). Perilaku Konsumen Teori dan Penerapannya dalam Pemasaran. Bogor: Ghalia Indonesia.

Syaefudin, A. (2017). Tertinggi, Kontribusi Industri Makanan dan Minuman Capai 34,17 Persen. Retrieved from katadata.com

Tandarto, R., \& Dharmayanti, D. (2017). Pengaruh Brand Awareness Terhadap Customer Loyalty dengan Celebrity Endorsement Raline Shah Sebagai Variabel Intervening TOP WHITE COFFEE di Surabaya, 4(1).

Vanessa, G. (2007). CRM dan MPR Hotel. Bandung: Alfabeta.

Wijayanto, I., \& Iriani, S. S. (2013). Pengaruh Citra Merek Terhadap Loyalitas Kosumen. Jurnal Ilmu Manajemen, 1(3), 910-918. 


\section{Apendiks 1}

VARIABEL, INDIKATOR, DAN ITEM

\begin{tabular}{|c|c|c|}
\hline Variabel & Indikator & Item \\
\hline \multirow{8}{*}{$\begin{array}{l}\text { Kesadaran } \\
\text { Merek }\left(\mathrm{X}_{1}\right)\end{array}$} & \multirow[b]{2}{*}{ Top Of Mind $\left(\mathrm{X}_{1.1}\right)$} & $\begin{array}{l}\text { Teh Pucuk Harum langsung muncul pertama kali dipikiran saya } \\
\text { ketika saya ingin membeli produk teh kemasan siap minum }\left(\mathrm{X}_{1.1 .1}\right)\end{array}$ \\
\hline & & $\begin{array}{l}\text { Saya langsung menyebutkan merek Teh Pucuk Harum ketika } \\
\text { membeli produk teh kemasan siap minum }\left(\mathrm{X}_{1.1 .2}\right)\end{array}$ \\
\hline & \multirow{3}{*}{ Brand Recall $\left(\mathrm{X}_{1.2}\right)$} & $\begin{array}{l}\text { Ketika melihat beberapa merek teh kemasan siap minum, saya } \\
\text { langsung memilih Teh Pucuk Harum }\left(X_{1.2 .1}\right)\end{array}$ \\
\hline & & $\begin{array}{l}\text { Saya secara spontan langsung memilih Teh Pucuk Harum tanpa } \\
\text { ada pemikiran terlebih dahulu }\left(\mathrm{X}_{1.2 .2}\right)\end{array}$ \\
\hline & & Teh Pucuk Harum merupakan pilihan utama saya $\left(\mathrm{X}_{1.2 .3}\right)$ \\
\hline & \multirow{3}{*}{ Brand Recognition $\left(\mathrm{X}_{1.3}\right)$} & Pernah terlintas Teh Pucuk Harum dalam pikiran saya $\left(\mathrm{X}_{1.3 .1}\right)$ \\
\hline & & Saya terkadang ingat Teh Pucuk Harum $\left(\mathrm{X}_{1.3 .2}\right)$ \\
\hline & & $\begin{array}{l}\text { Saya terkadang sulit mengimajinasikan merek Teh Pucuk Harum } \\
\left(\mathrm{X}_{1.3 .3}\right)\end{array}$ \\
\hline \multirow{11}{*}{ Citra Merek $\left(X_{2}\right)$} & \multirow{4}{*}{$\begin{array}{l}\text { Strenght of brand association } \\
\qquad\left(\mathrm{X}_{2.1}\right)\end{array}$} & Teh Pucuk Harum menawarkan harga yang terjangkau $\left(\mathrm{X}_{2.1 .1}\right)$ \\
\hline & & Teh Pucuk Harum memiliki kemasan yang praktis $\left(\mathrm{X}_{2.1 .6}\right)$ \\
\hline & & Teh Pucuk Harum mudah didapatkan $\left(\mathrm{X}_{2.1 .7}\right)$ \\
\hline & & Label kemasan Teh Pucuk Harum berwarna merah $\left(\mathrm{X}_{2.1 .8}\right)$ \\
\hline & \multirow{7}{*}{$\begin{array}{l}\text { Favorability of brand association } \\
\qquad\left(\mathrm{X}_{2.2}\right)\end{array}$} & Teh Pucuk Harum menawarkan harga yang terjangkau $\left(\mathrm{X}_{2.2 .1}\right)$ \\
\hline & & Teh Pucuk Harum memiliki rasa yang manis dan enak $\left(\mathrm{X}_{2.2 .2}\right)$ \\
\hline & & Iklan Teh Pucuk Harum yang unik dan menarik $\left(\mathrm{X}_{2.2 .3}\right)$ \\
\hline & & Teh Pucuk Harum memiliki ukuran kemasan yang variatif $\left(\mathrm{X}_{2.2 .4}\right)$ \\
\hline & & Tagline Teh Pucuk Harum yang mudah diingat $\left(\mathrm{X}_{2.2 .5}\right)$ \\
\hline & & Teh Pucuk Harum memiliki kemasan yang praktis $\left(\mathrm{X}_{2.2 .6}\right)$ \\
\hline & & Teh Pucuk Harum mudah didapatkan $\left(\mathrm{X}_{2.2 .7}\right)$ \\
\hline
\end{tabular}




\begin{tabular}{|c|c|c|}
\hline Variabel & Indikator & Item \\
\hline & & Iklan Teh Pucuk Harum yang unik dan menarik $\left(\mathrm{X}_{2.3 .3}\right)$ \\
\hline & & Teh Pucuk Harum memiliki ukuran kemasan yang variatif $\left(\mathrm{X}_{2.3 .4}\right)$ \\
\hline & & Tagline Teh Pucuk Harum yang mudah diingat $\left(\mathrm{X}_{2.3 .5}\right)$ \\
\hline & & Teh Pucuk Harum memiliki kemasan yang praktis $\left(X_{2.3 .6}\right)$ \\
\hline & & Teh Pucuk Harum mudah didapatkan $\left(X_{2.3 .7}\right)$ \\
\hline & & Label kemasan Teh Pucuk Harum berwarna merah $\left(\mathrm{X}_{2.3 .8}\right)$ \\
\hline \multirow{11}{*}{$\begin{array}{c}\text { Loyalitas } \\
\text { Pelanggan }\left(\mathrm{Y}_{1}\right)\end{array}$} & \multirow{3}{*}{$\begin{array}{l}\text { Makes regular repeat purchases } \\
\qquad\left(\mathrm{Y}_{1.1}\right)\end{array}$} & Saya membeli Teh Pucuk Harum untuk keseharian saya $\left(\mathrm{Y}_{1.1 .1}\right)$ \\
\hline & & $\begin{array}{l}\text { Saya tetap membeli Teh Pucuk Harum ketika sedang berada di } \\
\text { luar kota }\left(\mathrm{Y}_{1.1 .2}\right)\end{array}$ \\
\hline & & $\begin{array}{l}\text { Saya membeli Teh Pucuk Harum lagi ketika Teh Pucuk Harum } \\
\text { saya habis }\left(\mathrm{Y}_{1.1 .3}\right)\end{array}$ \\
\hline & \multirow[b]{2}{*}{$\begin{array}{l}\text { Purchases across product and } \\
\text { services lines }\left(\mathrm{Y}_{1.2}\right)\end{array}$} & Saya tertarik untuk membeli Teh Pucuk Harum rasa lainnya $\left(\mathrm{Y}_{1.2 .1}\right)$ \\
\hline & & $\begin{array}{l}\text { Saya tertarik untuk membeli Teh Pucuk Harum ukuran kemasan } \\
\text { lainnya }\left(\mathrm{Y}_{1.2 .2}\right)\end{array}$ \\
\hline & \multirow{3}{*}{ Refers others $\left(\mathrm{Y}_{1.3}\right)$} & $\begin{array}{l}\text { Saya mengajak teman saya untuk mencoba Teh Pucuk Harum } \\
\left(\mathrm{Y}_{1.3 .1}\right)\end{array}$ \\
\hline & & $\begin{array}{l}\text { Saya mengajak saudara-saudara dari keluarga saya untuk } \\
\text { mencoba Teh Pucuk Harum }\left(\mathrm{Y}_{1.3 .2}\right)\end{array}$ \\
\hline & & $\begin{array}{l}\text { Saya mengajak ibu, ayah, adik, maupun kakak untuk mencoba } \\
\text { Teh Pucuk Harum }\left(\mathrm{Y}_{1.3 .3)}\right.\end{array}$ \\
\hline & \multirow{3}{*}{$\begin{array}{l}\text { Demonstrates immunity to the } \\
\text { pull of the competition }\left(\mathrm{Y}_{1.4}\right)\end{array}$} & $\begin{array}{l}\text { Saya tidak tertarik untuk mencoba produk teh kemasan siap } \\
\text { minum lain selain Teh Pucuk Harum }\left(\mathrm{Y}_{1.4 .1}\right)\end{array}$ \\
\hline & & $\begin{array}{l}\text { Biasanya saya tidak terlalu terpengaruh dengan penawaran- } \\
\text { penawaran produk teh kemasan siap minum lainnya }\left(\mathrm{Y}_{1.4 .2}\right)\end{array}$ \\
\hline & & $\begin{array}{l}\text { Saya tidak terlalu ambil pusing pada promosi-promosi produk teh } \\
\text { kemasan siap minum lain yang ditawarkan pada saya }\left(\mathrm{Y}_{1.43}\right)\end{array}$ \\
\hline
\end{tabular}

\section{Sumber : data diolah penulis}

